\title{
The cavity under the Amery Ice Shelf, East Antarctica
}

\author{
B.K. GALTON-FENZI, ${ }^{1,2,3}$ C. MARALDI, ${ }^{4}$ R. COLEMAN, ${ }^{1,2,3}$ J. HUNTER ${ }^{1,3}$ \\ ${ }^{1}$ Centre for Marine Science, University of Tasmania, Private Bag 80, Hobart, Tasmania 7001, Australia \\ E-mail: bkgalton@utas.edu.au \\ ${ }^{2}$ CSIRO Marine and Atmospheric Research, Box 1538, Hobart, Tasmania 7001, Australia \\ ${ }^{3}$ Antarctic Climate and Ecosystems CRC, Box 252-80, Hobart, Tasmania 7001, Australia \\ ${ }^{4}$ Legos, 18 av. Edouard Belin, 31401 Toulouse Cedex, France
}

\begin{abstract}
Ocean circulation under ice shelves and associated rates of melting and freezing are strongly influenced by the shape of the sub-ice-shelf cavity. We have refined an existing method and used additional in situ measurements to estimate the cavity shape under the Amery Ice Shelf, East Antarctica. A finite-element hydrodynamic ocean-tide model was used to simulate the major tidal constituents for a range of different sub-Amery Ice Shelf cavity water-column thicknesses. The data are adjusted in the largely unsurveyed southern region of the ice-shelf cavity by comparing the complex error between simulated tides and in situ tides, derived from GPS observations. We show a significant improvement in the simulated tides, with a combined complex error of $1.8 \mathrm{~cm}$, in comparison with past studies which show a complex error of $\sim 5.3 \mathrm{~cm}$. Our bathymetry incorporates ice-draft data at the grounding line and seismic surveys, which have provided a considerable amount of new data. This technique has particular application when the water column beneath ice shelves is inaccessible and in situ GPS data are available.
\end{abstract}

\section{INTRODUCTION}

The ice shelves fringing Antarctica provide an important interface between the grounded ice sheet and the oceans (Vaughan and Arthern, 2007). Increased ocean temperature (and hence basal melting) has been implicated in the thinning of Pine Island Glacier, West Antarctica, and the collapse of parts of the Larsen Ice Shelf, Antarctic Peninsula (Shepherd and others, 2003, 2004). Numerical studies of simplified ice-shelf cavities show the strong effect that cavity shape has on basal melt rates (Holland and others, 2008). As such, ice draft and bathymetry are important parameters for numerical models which simulate sub-ice circulation patterns and melt/freeze rates (e.g. Nøst and Foldvik, 1994).

The Amery Ice Shelf (AIS) is the major embayed ice shelf of East Antarctica (Fig. 1) and drains 16\% of the grounded East Antarctic ice sheet through Lambert Glacier and other tributary glaciers (Allison, 1979). The geometry of the cavity beneath the AIS is thought to have a strong influence on the thermohaline circulation (Williams and others, 1998) and is important for sediment studies (e.g. Hemer and Harris, 2003), biological studies (e.g. Riddle and others, 2007) and palaeoclimate studies of past grounding-line positions (e.g. O'Brien and others, 2007).

The AIS cavity geometry and grounding line has been redefined a number of times since early modelling studies by Williams and others (1998). Fricker and others (2002) estimated that the southern limit of the grounding line was $240 \mathrm{~km}$ further south than prior estimates (Budd and others, 1982), and most recently L. Giovanna and others (personal communication from N. Young, 2007) used observations from moderate-resolution imaging spectroradiometer (MODIS) and synthetic aperture radar (SAR) studies to infer groundingline positions from the break in the surface slope topography (shown as the solid black curve in Fig. 1b).

Available bathymetry data beneath the AIS are restricted to regions that are easily accessed in the field and do not extend south of $71.6^{\circ} \mathrm{S}$ on the AIS, which is shown here to have a southern limit at $73.6^{\circ} \mathrm{S}$ (see Fig. 1a for data locations). As a consequence, the shape of the AIS cavity south of $71.6^{\circ} \mathrm{S}$ is largely unknown. Future seismic studies of the southern region are uncertain due to the location (the area has many crevasses and is riddled with summer surface melt features) and challenging logistics (the area is $>600 \mathrm{~km}$ from Davis, the nearest base station), although such surveys provide the most direct and accurate measurements of ice draft and water-column thickness. Any opportunity to make measurements in this region is probably many years away under current field-programme logistical support plans of the Australian Antarctic Division. These reasons necessitate the use of an alternative method to achieve a bathymetry that is as accurate as possible.

Here, we refine a method, first used by Hemer and others (2006), to determine the general cavity shape beneath the AIS. Hemer and others (2006) showed that the water-column thickness (WCT), which is the difference in depth between the ice-shelf draft and bathymetry, in the unknown areas beneath an ice shelf can be inferred with the aid of a tidal model. We have improved the method of Hemer and others by including the most up-to-date bathymetry and ice-draft data and modelling the tides at a much higher resolution. The original sparse bathymetry data have been supplemented with data from new seismic surveys, direct observations through boreholes in the floating ice shelf and ice-draft radar data, taken at the grounding line. The updated grounding-line position provided by N. Young (personal communication, 2007) is also used to provide the most upto-date map of the AIS cavity geometry.

We use a high-resolution hydrodynamic tidal model (MOG2D) to produce tidal predictions for ten different estimates of the WCT, with the values for WCT chosen to be within what we believe to be plausible ranges. These tidal predictions are then compared with GPS (global positioning system) observations of the tidal amplitude and phase measured at various locations on the AIS (see Fig. $1 \mathrm{~b}$ for GPS locations). The most appropriate WCT corresponds 

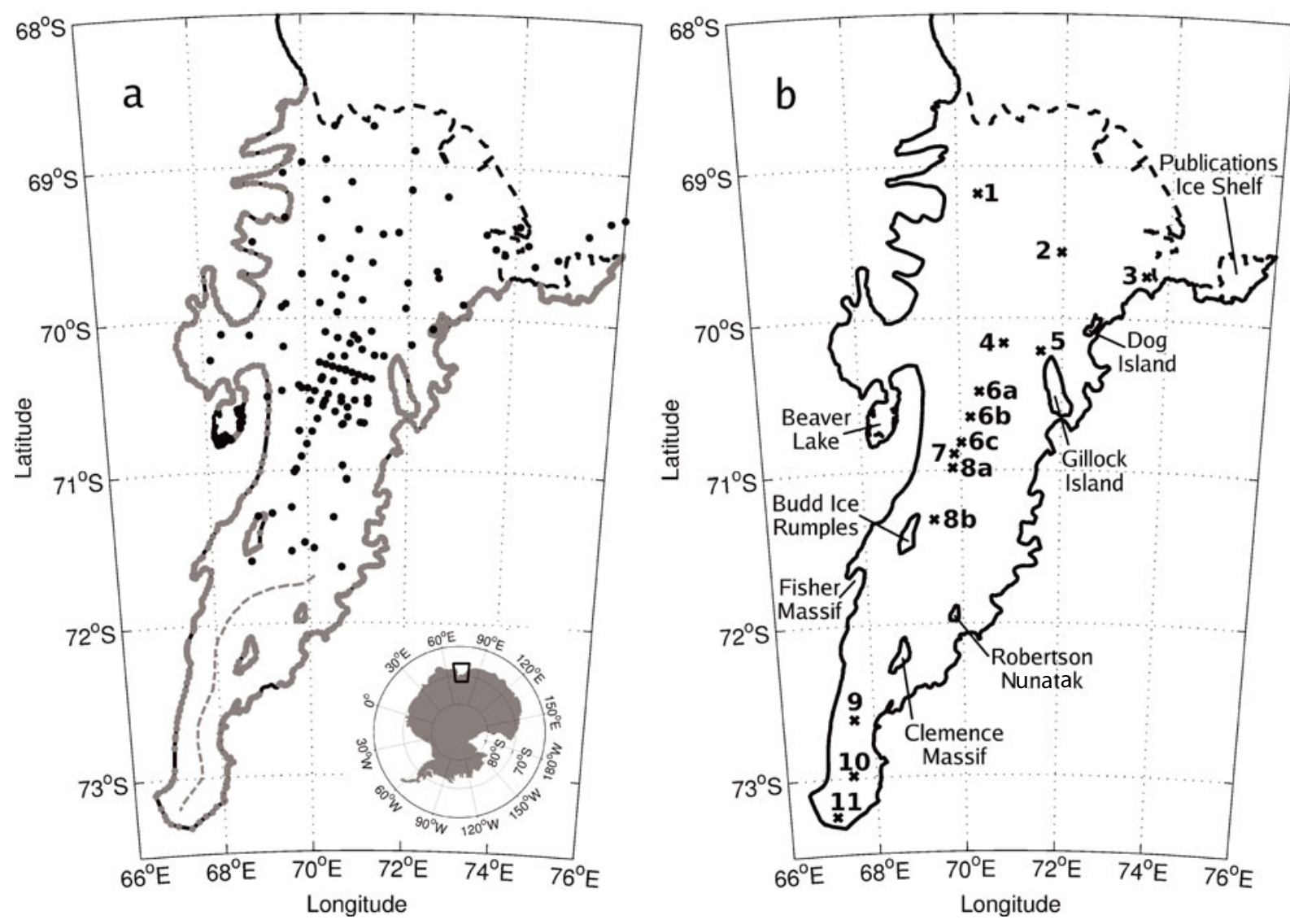

Fig. 1. The location of Amery Ice Shelf and Prydz Bay in East Antarctica (black box in inset). (a) The bathymetry data used in the interpolation: black dots show the location of the seismic data, the grey curve shows the ice-draft data taken at the grounding line and the dashed grey curve in the southern region of the AIS is the prescribed channel centre line. (b) The locations of the 11 GPS observation sites and major features of the Amery Ice Shelf region.

to the smallest difference of the complex sum between the observed and predicted harmonics for the four main tidal constituents $\left(\mathrm{K}_{1}, \mathrm{O}_{1}, \mathrm{~S}_{2}, \mathrm{M}_{2}\right)$, which represent $\sim 80 \%$ of the total tidal variance in this region.

This paper presents a refined cavity geometry for the AIS. Bathymetry data from seismic surveys and direct observations are supplemented here with ice-draft data taken at the grounding line. The grounding-line position for the AIS was taken as the point at which WCT goes to zero. All the available bathymetry data are combined and merged with bathymetry data in Prydz Bay to produce a final continuous bathymetry map beneath the AIS on a $2 \mathrm{~km} \times 2 \mathrm{~km}$ grid.

\section{AIS GEOMETRY DATA}

\section{Bathymetry}

Measurements of the cavity shape beneath ice shelves generally rely on data from seismic surveys and direct observations via boreholes through the ice. The largest single seismic study of the bathymetry covered $\sim 60 \%$ of the northern region beneath the AIS (Ruddell and Popov, 2001). This survey provided 72 usable data points. Seismic surveys conducted from 2002/03 to 2005/06 (Tassell, 2004; McMahon and Lackie, 2006), over five Antarctic summer seasons, were confined to areas that were more easily accessed and operationally safer. These seismic profiles covered the central part of the AIS and added another 35 data points. The error associated with converting the seismic reflections into a depth below mean sea level is $\sim 3 \mathrm{~m}$, due to uncertainty estimating the seismic velocity within the ice shelf (Tassell, 2004).

Direct observations of the bathymetry and ice thickness came from four boreholes drilled through the AIS as part of the ongoing Amery Ice Shelf Ocean Research (AMISOR) project (Allison, 2003). In addition, Bardin and others (1990) obtained direct measurements of the Beaver Lake nearshore bathymetry, via holes drilled through the fast ice, from which we use 12 data points. Note that the agreement in the WCT data between different seismic surveys and direct observations made in the same area is within $\sim 5 \mathrm{~m}$.

The surface height above mean sea level was estimated by subtracting the ellipsoidal height of mean sea level (using the EIGEN-GRACE02S geopotential model of Forschungszentrum Jülich/Centre National d'Études Spatiales, France; Reigber and others, 2005) from the GPS ellipsoidal height of the surface at the seismic site. Uncertainties in the geoid model introduce an error of about $\pm 1 \mathrm{~m}$ (personal communication from R. Hurd, 2007).

\section{Ice draft}

Surface elevations and ice thicknesses have been measured over much of the area using satellite radar altimeter and radio-echo sounding. The elevation and thickness estimates of Fricker and others $(2000,2002)$ are used here. The ice drafts were found by subtracting the elevation from the icethickness data. The ice-draft data were then resampled onto a $2 \mathrm{~km}$ grid using nearest-neighbour interpolation, which also removed gaps in the dataset. This resulted in a continuous 
ice-draft map for the entire area of the AIS, which is shown in Figure 2.

The uncertainty in the observations was estimated by comparing the gridded ice draft with independent radio-echo sounding measurements of ice thickness collected as part of the Prince Charles Mountains Expedition of Germany and Australia (PCMEGA) campaign during the 2002/03 Antarctic summer. We find that the PCMEGA data, which are only available for the southernmost region of the AIS, are $\sim 3 \%$ thicker than the gridded ice-draft data. This is $\sim 75 \mathrm{~m}$ at the deepest part of the ice shelf which is $\sim 2500$ m below mean sea level at its southern extremity. This error in the earlier gridded ice-draft data is probably due to underestimating the ice density in regions of higher ablation, which is typically where the ice shelf is thickest, as in the southern region of the AIS (personal communication from H. Fricker, 2007). We have found that the southernmost grounding line is deeper than BEDMAP estimates by $\sim 450 \mathrm{~m}$ (Lythe and others, 2000) and is one of the deepest grounding lines of any ice shelf.

\section{Gridding method}

Ice-draft data at the grounding line were extremely useful in the interpolation of the bathymetry. The grounding line is where the base of the ice shelf coincides with the sea floor. It is important to include these data in the interpolation because they help constrain the shape of the AIS cavity. The ice-draft data were interpolated using nearest-neighbour interpolation to each known grounding-line location, which is made up of 1317 points. The grounding-line locations are shown as the grey curve in Figure 1a. Note that this is made up of individual inferences of the grounding-line position. The combined dataset, involving both bathymetry and grounding-line locations, contained 1436 data points compared with only 72 in the work of Hemer and others (2006).

The $2 \mathrm{~km} \times 2 \mathrm{~km}$ grid covered the Prydz Bay depression from $66^{\circ} \mathrm{E}$ to $79^{\circ} \mathrm{E}$ and from the southernmost extension of the AIS at $73.6^{\circ} \mathrm{S}$ to the shelf break at $\sim 66^{\circ} \mathrm{S}$. This created $120291(397 \times 303)$ interpolation sites. All available sub-ice-shelf bed-elevation data and Prydz Bay bathymetry data (a combination of ship-track measurements supplied by the Australian Antarctic Division Data Centre and the General Bathymetric Chart of the Oceans (GEBCO) 1 min bathymetric data of IOC and others, 2003) were interpolated onto the model grid using a Universal Transverse Mercator projection (WGS84). The bathymetry data were gridded using a kriging technique with an isotropic variogram which was linear within the correlation radius and zero outside. The correlation radius was chosen to be $6 \mathrm{~km}$, based on the average data density in the northern region of the AIS. The standard error introduced by the kriging technique can be calculated by comparing the elevation from the interpolated grid with the observations at each location. This yields a standard error in the bathymetry interpolation, excluding the ice-draft data taken at the grounding line, of about $\pm 6 \mathrm{~m}$. The standard error in the bathymetry interpolation at the grounding line is about $\pm 2 \mathrm{~m}$. The lower standard error at the grounding line is due to the higher data density in this region.

A range of ten possible choices of bathymetry was created by incorporating synthetic data into the interpolation from along the prescribed channel centre line, which is shown as the dashed grey curve in Figure 1a. Each of the ten choices of bathymetry used a single prescribed value of WCT that was added to the value of the overlying ice draft along the

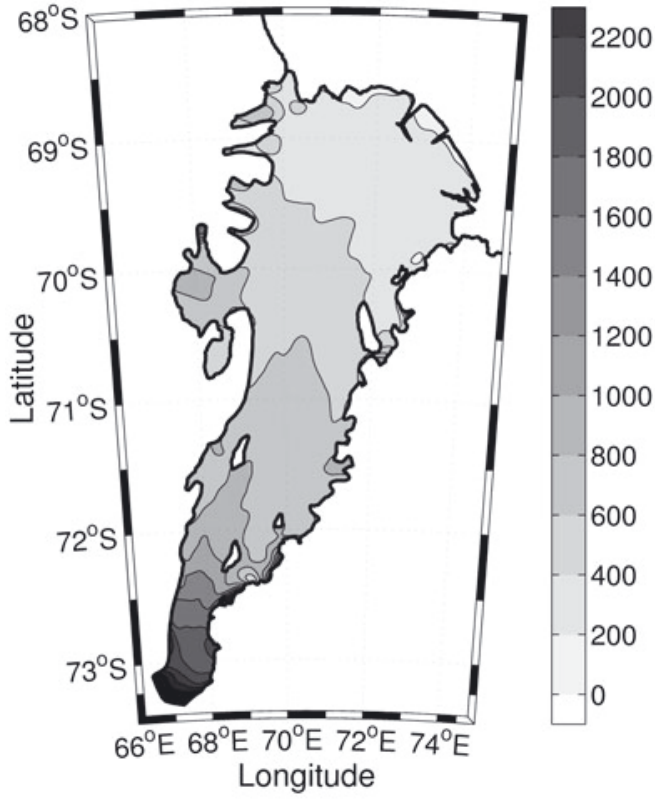

Fig. 2. Ice draft of the AIS showing $200 \mathrm{~m}$ contour intervals.

channel centre line. The values added to the ice draft along the channel centre line were 170, 470, 770, 1070, 1370, $1670,1970,2270,2570$ and $2870 \mathrm{~m}$. The effect can be seen in Figure 3, which shows the range of south-north and east-west profiles created, following the two transects shown in the inset of Figure 3a. The WCT was constrained to a minimum of $10 \mathrm{~m}$. The tidal model requires just the WCT, which was calculated from the difference between the bathymetry and the ice draft.

\section{TIDE MODEL}

Each choice of WCT was tested in MOG2D, which is a barotropic time-stepping and non-linear two-dimensional (vertically averaged) gravity-wave model, based on that of Lynch and Gray (1979). In regions where there is an iceshelf cavity, the WCT (rather than the depth of the sea floor) is the appropriate 'water depth' to use in the model. MOG2D computes the sea-surface height and mean currents due to wind and tidal forcing by solving the shallow-water momentum and continuity equations on a finite-element mesh. This spatial discretization allows the resolution to be coarser in the deep ocean and finer in coastal regions and those with strong topographic gradients, enabling good simulation of gravity waves. The spatial resolution is based on the WCT, its gradient and the wavelength of the gravity waves (Le Provost and Vincent, 1986).

The model domain covers the southern area of the Indian Ocean with a grid ranging in size from a few kilometres on the continental shelf, including the AIS region, to $100 \mathrm{~km}$ in the deep ocean. Details of the finite-element mesh are given by Maraldi and others (2007). By calculating tides for a range of plausible WCTs in unsampled areas in the southern AIS, we can produce a map of WCT values that provides the optimum agreement between modelled and measured (GPS) tides.

The coefficient used for tidal bottom friction parameterization was taken to be 0.0025 and, following other studies, was doubled for the area covered by the ice shelf (e.g. 

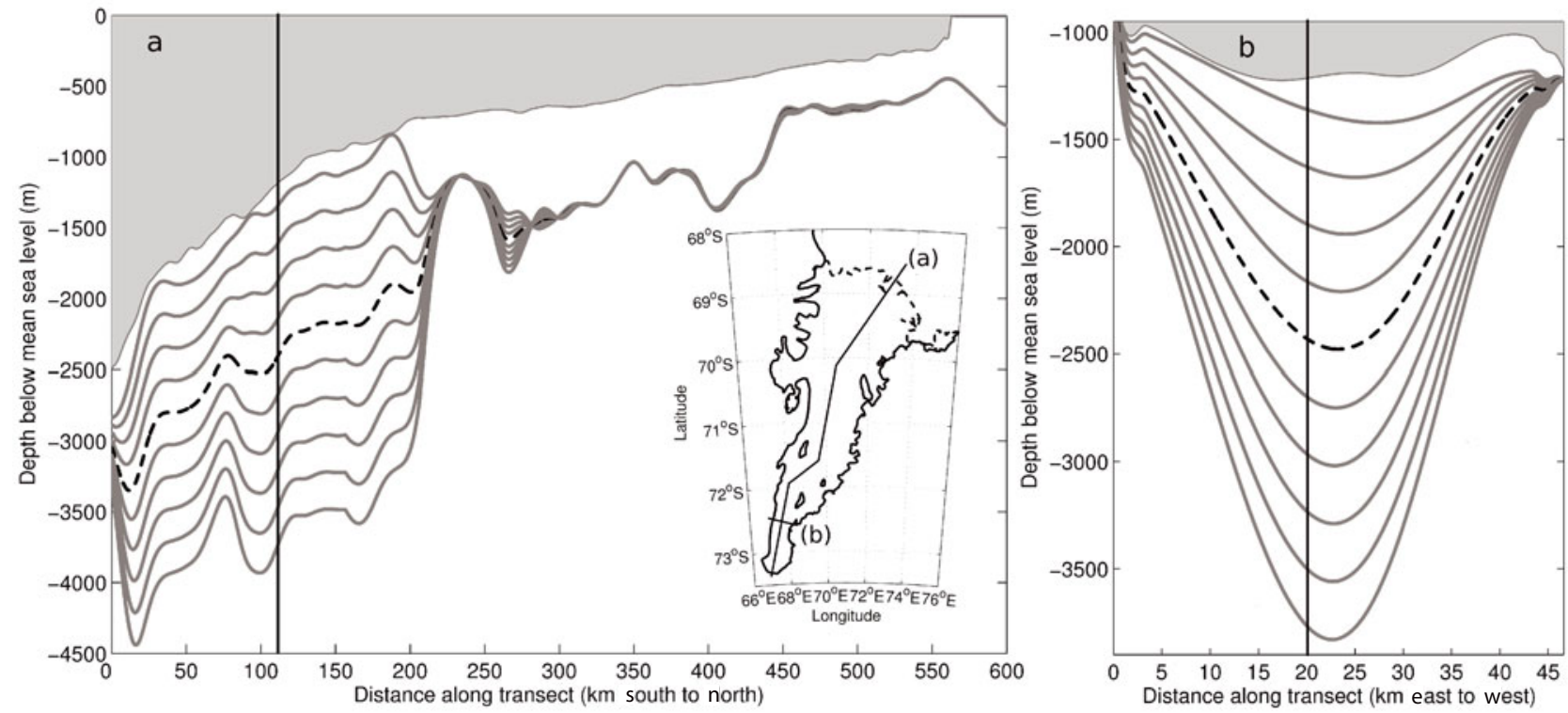

Fig. 3. Vertical sections along transects (a) south-north and (b) east-west as shown in the inset. Ten possible choices of bathymetry are shown. The best estimate is the black dashed curve. Each bathymetric choice was created by varying the thickness of the water column below the ice shelf along the dashed grey curve shown in Figure 1a. The intersection point of the two transects is shown in (a) and (b) by a vertical black line.

MacAyeal, 1984). Dissipation due to ice-shelf flexure caused by the tidal motion is not accounted for at the grounding line; the ice shelf is considered to be freely floating. The open boundaries are forced using the harmonic constants (amplitude and phase) obtained from the FES2004 global barotropic solution (Lyard and others, 2006). Three semidiurnal $\left(\mathrm{M}_{2}, \mathrm{~S}_{2}, \mathrm{~N}_{2}\right)$ and three diurnal $\left(\mathrm{K}_{1}, \mathrm{O}_{1}, \mathrm{P}_{1}\right)$ tidal constituents were modelled. The model was run for 40 days, including a 3 day spin-up period. The harmonic analysis was performed on the last 30 days so that each of the constituents was well resolved.

\section{DATA ANALYSIS}

GPS data from 11 records were used to validate the tide model (see Table 1). Tidal amplitude and phase for the four main constituents were found for each GPS record. GPS data from sites 1, 2, 3, 5 and 11 (Fig. $1 \mathrm{~b}$ ) have records long enough that tidal analysis may resolve $\mathrm{M}_{2}$ from $\mathrm{S}_{2}$ and $\mathrm{K}_{1}$ from $\mathrm{O}_{1}$ (i.e. $>15$ days). Records shorter than this were analysed for $M_{2}$ and $K_{1}$, where $S_{2}$ and $O_{1}$ were deduced using amplitude and phase relationships from the longer tidal records from Davis station. The errors in analysing specific constituents from short record lengths (i.e. less than $\sim 3-4$ days) can be large. We combined sites that had short length records and were within $20 \mathrm{~km}$ of each other to make longer time series to reduce this error: record 6 is a concatenation of sites $6 a$, $6 \mathrm{~b}$ and $6 \mathrm{c}$ and record 8 is a concatenation of sites $8 \mathrm{a}$ and $8 \mathrm{~b}$ (Fig. 1b; Table 1). Typical GPS measurement precisions are $\sim 1-5 \%$ of the tidal range, which for the AIS are $\sim 1-5 \mathrm{~cm}$ (King, 2002, 2006; Zhang and Andersen, 2006).

For each choice of WCT, the tidal solutions from MOG2D as a time series were compared to the GPS ellipsoidal height data that were measured over the AIS (see the crosses in Fig. $1 \mathrm{~b}$ for the locations). The sensitivity of the model to changes in the WCT is obtained using the modulus of the complex difference between observations and model predictions (the 'complex error'), which is calculated as:

$$
\epsilon=\left|z_{\text {observations }}-z_{\text {predictions }}\right|,
$$

where $z=A \mathrm{e}^{\mathrm{i} \phi}, A$ and $\phi$ being the amplitude $(\mathrm{cm})$ and phase, respectively, of each tidal constituent $M_{2}, S_{2}, K_{1}$ and $\mathrm{O}_{1}$. The root-mean-square (rms) error was calculated using

$$
\mathrm{rms}^{2}=\frac{1}{N} \sum_{i=1}^{N} \epsilon_{i}^{2},
$$

where $N$ is the total number of tidal constituents. The sensitivity of the model to changes in the WCT is shown in Figure 4.

\section{RESULTS AND DISCUSSION}

A significant minimum can be seen in the rms error for the simulations (Fig. 4). Summing over GPS records 1-10 shows that the smallest rms between the observations and simulations is for a mean WCT of $367 \mathrm{~m}$ (Fig. 4a), which is $\sim 35 \mathrm{~m}$ deeper than that estimated by Hemer and others (2006). In this case, the WCT along the prescribed channel centre line was $1370 \mathrm{~m}$, which is $\sim 750 \mathrm{~m}$ deeper than Hemer and others (2006). Record 11 (Fig. 4d) was excluded from Figure $4 \mathrm{a}$ as it lies in the ice-shelf flexure zone, which can act to damp the tidal amplitude. Ice-shelf flexure is a physical process that is not modelled in MOG2D, which is reflected in the larger rms shown in Figure $4 \mathrm{~d}$. The records in the adjusted southern region (records 8-11, Fig. 4c and d) show an increase in the rms toward the southern grounding line of the AIS. Records 8-10 (Fig. 4c) are clearly important contributors for the minimum rms seen in Figure 4a. Otherwise, the records to the north of the cavity (Fig. 4b) are essentially flat and do not contribute significantly to the shape of Figure 4a.

Comparison of the rms errors for the optimum WCT $(367 \mathrm{~m})$ with the rms errors from Hemer and others (2006) shows a significant improvement over all the GPS sites 
(Table 1). This is especially obvious in the southern region of the AIS for sites 9 and 10 where MOG2D shows large improvements in the semi-diurnal $\left(\mathrm{M}_{2}, \mathrm{~S}_{2}\right)$ and diurnal $\left(\mathrm{K}_{1}\right.$, $\mathrm{O}_{1}$ ) tides. Note that Maraldi and others (2007) have shown that MOG2D with the best-fit WCT profile has also been found to outperform the regional Antarctic models (CATS and CADA (Padman and others, 2002) and global tide models, TPXO (Egbert and others, 1994) and FES2004 (Lyard and others, 2006)). These improvements are therefore due to both the higher resolution of the tide model and the improved ice draft and bathymetry.

\section{Best-fit cavity geometry}

We have produced a refined map of the AIS bathymetry. The new bathymetry map (Fig. 5a) was derived using ice-draft data at the grounding line and a prescribed channel centre line which has the advantage of retaining the cross-sectional aspect of the ice-shelf geometry. Sections through the best-fit bathymetry are shown by the dashed black curve in Figure 3 . The differences between the bathymetry of Hemer and others (2006) and this study are shown in Figure 5b. The main differences occur in the area south of $71.5^{\circ} \mathrm{S}$. Most of the change seen in the northern part of the AIS can be attributed to the new grounding-line position and the seismic and borehole data. The best fit continues the north-south trend in the bathymetry that can be seen in the northern part of the cavity (Fig. 3a).

The total area of the AIS, less any area covered by Budd Ice Rumples, Clemence Massif, Robertson Nunatak and Gillock and Dog Islands, is $58380 \mathrm{~km}^{2}$. This estimate is $5 \%$ larger than the area used by Hemer and others (2006) (the differences between grounding-line positions can be seen in the dotted dark grey and light grey areas of Figure $5 b)$ and $15 \%$ larger than suggested by Fricker and others (2002). Most of the difference in area estimates is seen in the southern grounding-line position. This estimate uses an ice-front position from 2001 which is advancing at a rate of $\sim 1200 \mathrm{~m} \mathrm{a}^{-1}$ (Young and Hyland, 2002). The total area of the AIS at the time of writing is therefore $\sim 60000 \mathrm{~km}^{2}$.

Obtaining a realistic description of the cavity shape is especially important for studies of the ocean circulation in the sub-ice-shelf cavity. This circulation can be described
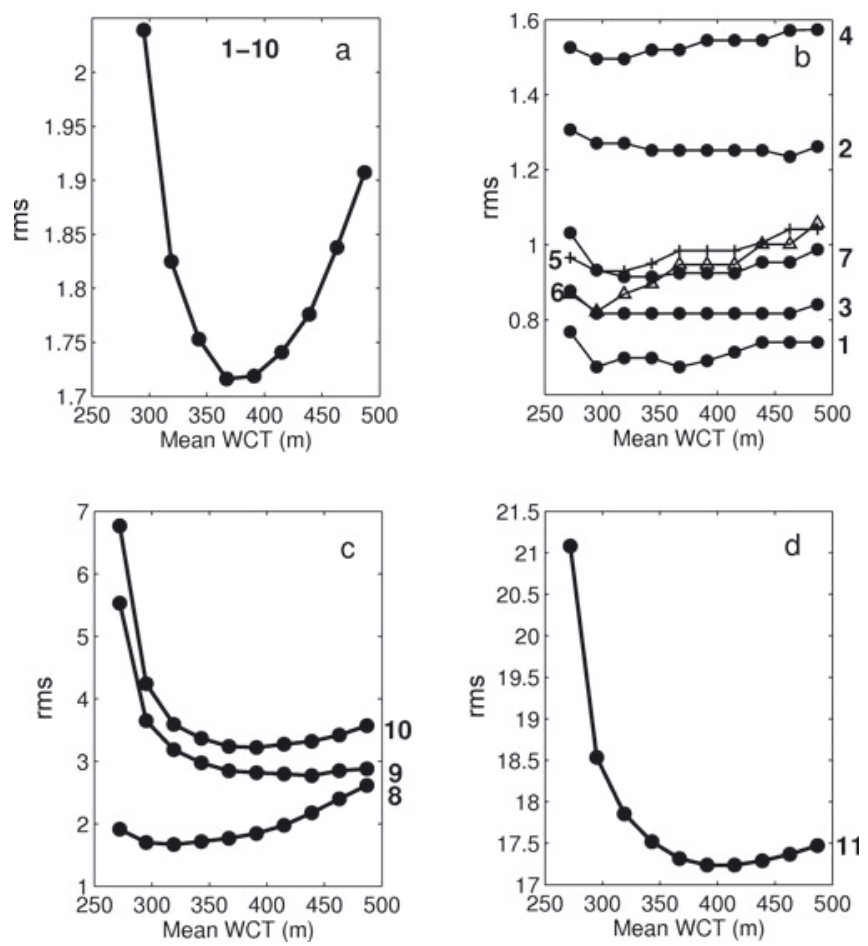

Fig. 4. The sum of the rms complex errors for the four major tides compared with the mean WCT calculated over the AIS, for (a) the sum of records $1-10$, (b) records $1-7$, (c) records 8-10 and (d) record 11. Note that record 11 lies within the ice-shelf flexure zone, which acts to damp the tidal amplitude, thereby increasing the complex error, and so was not included in (a).

thus: When water at or near the surface freezing point (e.g. high-salinity shelf water) descends into the cavity beneath the ice shelf, it can cause melting near the back of the shelf due to the depression of the freezing point with pressure. The subsequent freshened water (ice-shelf water) can rise along the underside of the shelf and possibly refreeze to the base of the ice shelf, forming marine ice (Lewis and Perkin, 1986). Any flow of dense marine waters from Prydz Bay (e.g. high-salinity shelf water) is expected to follow

Table 1. The complex error, $\epsilon(\mathrm{cm})$ for this study (TS) and Hemer and others (2006) (H06) for GPS sites $1-11$. The bottom row is the root-mean-square value calculated over sites 1-10. Site 11 is excluded from the rms calculation as it lies in the ice-shelf flexure zone

\begin{tabular}{|c|c|c|c|c|c|c|c|c|c|c|}
\hline \multirow[t]{2}{*}{ Record } & \multirow{2}{*}{$\begin{array}{l}\text { Length } \\
\text { days }\end{array}$} & \multirow[t]{2}{*}{ ID } & \multicolumn{2}{|c|}{$\mathrm{M}_{2}$} & \multicolumn{2}{|c|}{$\mathrm{S}_{2}$} & \multicolumn{2}{|c|}{$\mathrm{K}_{1}$} & \multicolumn{2}{|c|}{$\mathrm{O}_{1}$} \\
\hline & & & TS & H06 & TS & H06 & TS & H06 & TS & H06 \\
\hline 1 & 48 & TS03 & 0.6 & 2.1 & 0.7 & 2.2 & 0.9 & 4.1 & 0.5 & 8.2 \\
\hline 2 & 68 & TS01 & 1.3 & 2.4 & 0.9 & 0.5 & 1.9 & 6.1 & 0.4 & 5.5 \\
\hline 3 & 26 & HWDT & 0.4 & 1.6 & 1.1 & 0.7 & 1.1 & 0.8 & 0.3 & 2.9 \\
\hline 4 & 1.8 & G2 & 0.1 & 5.5 & 1.6 & 2.2 & 1.3 & 6.1 & 2.3 & 5.3 \\
\hline 6 & 3.3 & $\mathrm{C} 12,10,8$ & 0.6 & - & 0.4 & - & 1.1 & - & 1.3 & - \\
\hline 7 & 11 & CAMP & 0.9 & 1.5 & 1.1 & 4.5 & 0.6 & 3.5 & 1.1 & 2.1 \\
\hline 8 & 2.3 & C6,2 & 1.7 & - & 2.3 & - & 1.7 & - & 1.6 & - \\
\hline 9 & 3.5 & V3 & 2.6 & 12.1 & 3.0 & 10.2 & 3.2 & 3.7 & 2.4 & 3.8 \\
\hline 10 & 3.8 & V5 & 2.9 & 9.1 & 3.2 & 8.3 & 3.8 & 4.5 & 2.9 & 4.0 \\
\hline 11 & 83 & TS05 & 17.2 & - & 18.3 & - & 16.9 & - & 16.5 & - \\
\hline rms & & & 1.6 & 5.9 & 1.9 & 5.1 & 2.1 & 4.8 & 1.7 & 5.4 \\
\hline
\end{tabular}

Note: Record 6 is combined from sites $6 a(1.13), 6 b(1.2)$ and $6 c(0.96)$, and record 8 is combined from sites $8 a(1.0)$ and $8 b(1.3)$. See Figure $1 \mathrm{~b}$ for locations. 

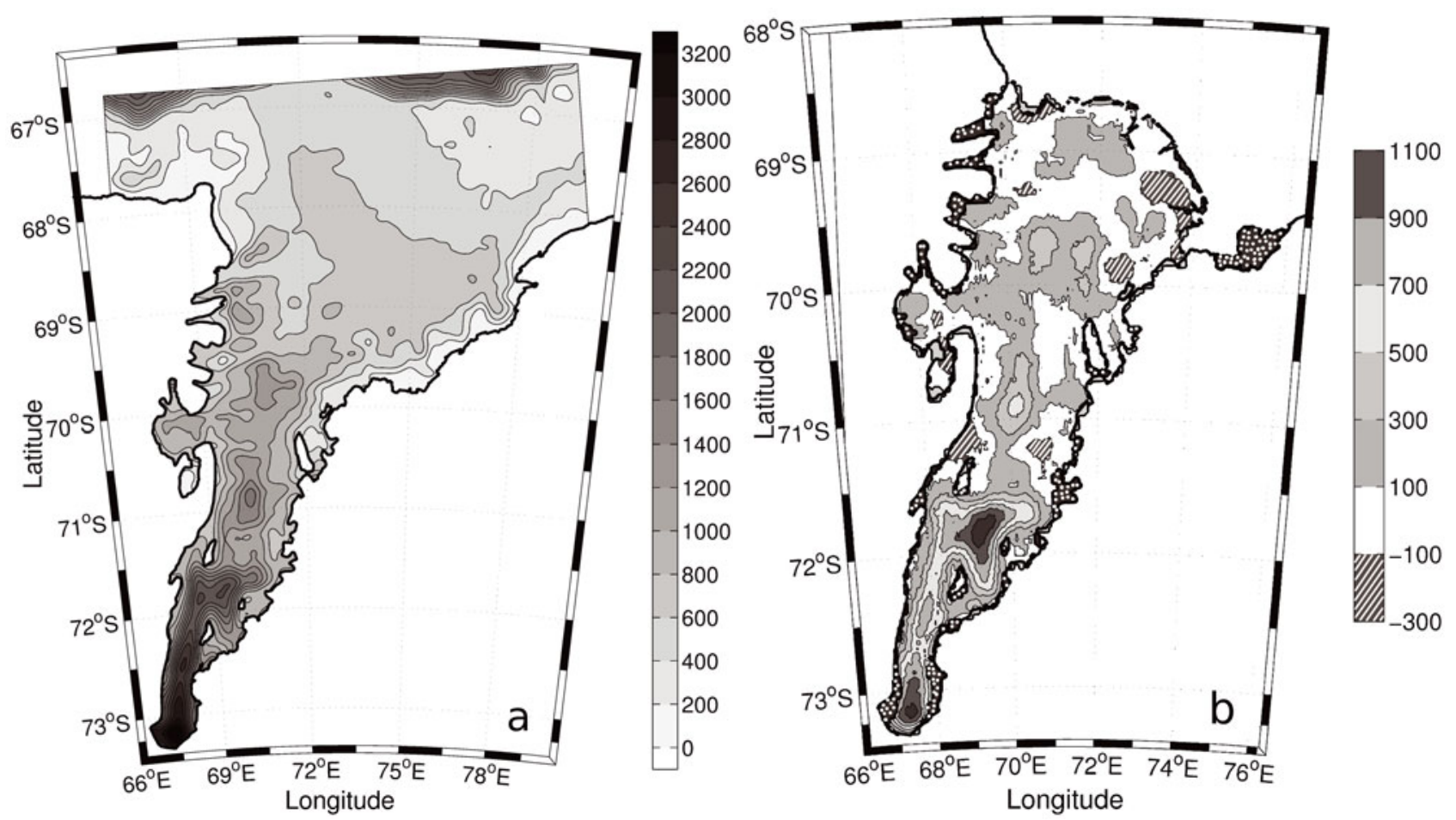

Fig. 5. (a) The resulting bathymetry of the AIS and Prydz Bay regions showing $200 \mathrm{~m}$ contour intervals. (b) Difference between this bathymetry and that of Hemer and others (2006), the extra area included in this study indicated as spotted dark grey, and the extra area used by Hemer and others (2006) shown as light grey (i.e. in some regions near the grounding line such as in Beaver Lake).

the sea-floor contours. The new bathymetry map (Fig. 5a) suggests that the flow of dense marine waters into the cavity could follow the contours to the very southern grounding line. The ice draft at this depth is $1600 \mathrm{~m}$ deeper than that used in studies by Williams and others (2001); this has major implications for the amount of melting that can occur in this region.

\section{CONCLUSIONS}

We have refined a technique that was first used by Hemer and others (2006) to estimate the bathymetry beneath ice shelves in areas where direct observations are not feasible. We have used a high-resolution barotropic tide model together with GPS-derived tidal heights to estimate the shape of the cavity in the southern region beneath the AIS. New data from seismic-reflection studies undertaken in the centre of the AIS and ice-draft values taken at the grounding line have been used in a kriging interpolation to grid a continuous bathymetry at $2 \mathrm{~km} \times 2 \mathrm{~km}$ resolution. The higher resolution of the coastline and bathymetry is shown to deliver significant improvements in tidal elevation predictions in the region beneath the AIS (see Table 1). These results will be of interest to a broad range of disciplines, such as remote sensing, numerical modelling, oceanography and glaciology. These data can be accessed at http://aadcmaps.aad.gov.au

This method can be used to determine the WCT beneath other ice shelves and, with the inclusion of ice-draft data, the cavity bathymetry. This technique can use any surfaceelevation data which are of sufficient resolution to resolve tides. Sea-surface elevations, derived from satellite altimetry at crossover points, are a prime example, as demonstrated by Fricker and Padman (2002). The altimeter data generally allow better spatial coverage of the ice shelves and produce longer time series, making their use with this technique worth investigation.

These results confirm that the AIS cavity allows the oceans to be in contact with ice at the deepest point known for an Antarctic ice shelf; this has interesting consequences both in terms of glaciology and oceanography.

\section{ACKNOWLEDGEMENTS}

We thank N. Young for the updated grounding-line position; $H$. Fricker for AIS elevation and thickness estimates; H. Tassell and K. McMahon for new seismic data; R. Hurd and M. Craven for assistance finding the GPS and bathymetry data; M. Hemer for providing the Hemer and others (2006) modelling results and F. Lyard for providing MOG2D. We also thank two anonymous reviewers for their thorough review of the manuscript. This work is supported by the Australian Government Cooperative Research Centers Programme, through the Antarctic Climate and Ecosystems CRC.

\section{REFERENCES}

Allison I. 1979. The mass budget of the Lambert Glacier drainage basin, Antarctica. J. Glaciol., 22(87), 223-235.

Allison, I. 2003. The AMISOR project: ice shelf dynamics and iceocean interaction of the Amery Ice Shelf. FRISP Rep. 14, 74-82.

Bardin, V.I., A.A. Piskun and N.A. Shmideberg. 1990. [Hydrological and hydrochemical characteristics of deep water basins in Prince Charles Mountains.]. Antarkt., Dokl. Kom., 29, 97-112.

Budd, W.F., M.J. Corry and T.H. Jacka. 1982. Results from the Amery Ice Shelf Project. Ann. Glaciol., 3, 36-41. 
Egbert, G.D., A.F. Bennett and M.G.G. Foreman. 1994. TOPEX/ POSEIDON tides estimated using a global inverse model. J. Geophys. Res., 99(C12), 24, 821-24, 852.

Fricker, H.A. and L. Padman. 2002. Tides on Filchner-Ronne Ice Shelf from ERS radar altimetry. Geophys. Res. Lett., 29(12), 1622. (10.1029/2001GL014175.)

Fricker, H.A., G. Hyland, R. Coleman and N.W. Young. 2000. Digital elevation models for the Lambert Glacier-Amery Ice Shelf system, East Antarctica, from ERS-1 satellite radar altimetry. J. Glaciol., 46(155), 553-560.

Fricker, H.A. and 9 others. 2002. Redefinition of the Amery Ice Shelf, East Antarctica, grounding zone. J. Geophys. Res., 107(B5), 2092. (10.1029/2001JB000383.)

Hemer, M.A. and P.T. Harris. 2003. Sediment core from beneath the Amery Ice Shelf, East Antarctica, suggests mid-Holocene iceshelf retreat. Geology, 31(2), 127-130.

Hemer, M.A., J.R. Hunter and R. Coleman. 2006. Barotropic tides beneath the Amery Ice Shelf. J. Geophys. Res., 111 (C11), C11008. (10.1029/2006JC003622.)

Holland, P.R., A. Jenkins and D.M. Holland. 2008. The response of ice shelf basal melting to variations in ocean temperature. J. Climate, 21(11), 2558-2572.

IOC, IHO and BODC. 2003. Centenary edition of the GEBCO Digital Atlas published on CD-ROM on behalf of the Intergovernmental Oceanographic Commission and the International Hydrographic Organization as part of the General Bathymetric Chart of the Oceans, British Oceanographic Data Centre, Liverpool, UK.

King, M.A. 2002. The dynamics of the Amery Ice Shelf from a combination of terrestrial and space geodetic data. (PhD thesis, University of Tasmania.)

King, M. 2006. Kinematic and static GPS techniques for estimating tidal displacements with application to Antarctica. J. Geodyn., 41(1-3), 77-86.

Le Provost, C. and P. Vincent. 1986. Some tests of precision for a finite element model of ocean tides. J. Comput. Phys., 65(2), 273-291.

Lewis, E.L. and R.G. Perkin. 1986. Ice pumps and their rates. J. Geophys. Res., 91(C10), 11, 756-11, 762.

Lyard, F., F. Lefevre, T. Letellier and O. Francis. 2006. Modelling the global ocean tides: modern insights from FES2004. Ocean Dyn., 56(5-6), 394-415.

Lynch, D.R. and W.G. Gray. 1979. A wave equation model for finite element tidal computations. Comput. Fluids, 7 (3), 207-228.

Lythe, M.B., D.G. Vaughan and the BEDMAP Consortium. 2000. BEDMAP - bed topography of the Antarctic. 1:10000000 scale map. BAS (Misc) 9. Cambridge, British Antarctic Survey.

MacAyeal, D.R. 1984. Numerical simulations of the Ross Sea tides. J. Geophys. Res., 89(C1), 607-615.

Maraldi, C., B. Galton-Fenzi, F. Lyard, L. Testut and R. Coleman. 2007. Barotropic tides of the Southern Indian Ocean and the Amery Ice Shelf cavity. Geophys. Res. Lett., 34(18), L18602. (10.1029/2007GL030900.)
McMahon, K.L. and M.A. Lackie. 2006. Seismic reflection studies of the Amery Ice Shelf, East Antarctica: delineating meteoric and marine ice. Geophys. J. Int., 166(2), 757-766.

Nøst, O.A. and A. Foldvik. 1994. A model of ice shelfocean interaction with application to the Filchner-Ronne and Ross Ice Shelves. J. Geophys. Res., 99(C7), 14,243$14,254$.

O'Brien, P.E., I. Goodwin, C.-F. Forsberg, A.K. Cooper and J. Whitehead. 2007. Late Neogene ice drainage changes in Prydz Bay, East Antarctica and the interaction of Antarctic ice sheet evolution and climate. Palaeogeogr., Palaeoclimatol., Palaeoecol., 245(3-4), 390-410.

Padman, L., H.A. Fricker, R. Coleman, S. Howard and L. Erofeeva. 2002. A new tide model for the Antarctic ice shelves and seas. Ann. Glaciol., 34, 247-254.

Reigber, C. and 7 others. 2005. An Earth gravity field model complete to degree and order 150 from GRACE: EIGENGRACE02S. J. Geodyn., 39(1), 1-10.

Riddle, M.J., M. Craven, P.M. Goldsworthy and F. Carsey. 2007. A diverse benthic assemblage $100 \mathrm{~km}$ from open water under the Amery Ice Shelf, Antarctica. Paleoceanography, 22(P12), P1204. (10.1029/2006PA001327.)

Ruddell, A. and S. Popov. 2001 Maps of ice draft and bed elevation from seismic surveys over the Amery Ice Shelf. Hobart, Antarctic Cooperative Research Centre.

Shepherd, A., D. Wingham, T. Payne and P. Skvarca. 2003. Larsen ice shelf has progressively thinned. Science, 302(5646), 856-859.

Shepherd, A., D. Wingham and E. Rignot. 2004. Warm ocean is eroding West Antarctic Ice Sheet. Geophys. Res. Lett., 31(23), L23404. (10.1029/2004GL021106.)

Tassell, H. 2004. Seismic investigation into the ice thickness and seabed topography beneath the Amery Ice Shelf, East Antarctica. (PhD thesis, University of Tasmania.)

Vaughan, D.G. and R. Arthern. 2007. Climate change: why is it hard to predict the future of ice sheets? Science, 315(5818), 1503-1504.

Williams, M.J.M., A. Jenkins and J. Determann. 1998. Physical controls on ocean circulation beneath ice shelves revealed by numerical models. In Jacobs, S.S. and R.F. Weiss, eds. Ocean, ice and atmosphere: interactions at the Antarctic continental margin. Washington, DC, American Geophysical Union, 285-300. (Antarctic Research Series 75.)

Williams, M.J.M., K. Grosfeld, R.C. Warner, R. Gerdes and J. Determann. 2001. Ocean circulation and ice-ocean interaction beneath the Amery Ice Shelf, Antarctica. J. Geophys. Res., 106(C10), 22, 383-22, 399.

Young, N.W. and G. Hyland. 2002. Velocity and strain rates derived from InSAR analysis over the Amery Ice Shelf, East Antarctica. Ann. Glaciol., 34, 228-234.

Zhang, X. and O.B. Andersen. 2006. Surface ice flow velocity and tide retrieval of the Amery Ice Shelf using precise point positioning. J. Geod., 80(4), 171-176. 